\title{
Perkembangan perguruan islam Al-KHAIRIYAH CILEgON BANTEN (1916-1950)
}

\author{
The Development of Islamic Education Institution \\ A/ Khairiyah Cilegon Banten \\ (1916-1950)
}

\section{Oleh Herry Wiryono}

Balai Pelestarian Sejarah dan Nilai Tradisional Bandung. Jalan Cinambo No. 136, Ujung Berung Bandung

Email: heriwiryono@yahoo.com

\begin{abstract}
Abstrak
Perjuangan masyarakat Cilegon Banten dalam menghadapi kaum penjajah dilakukan dengan berbagai cara. Cara yang dianggap paling efektif untuk menghadapinya adalah melalui pendidikan. K.H Syam'un sebagai salah seorang ulama di Cilegon mempunyai harapan dan idealisme yang tinggi untuk mengembangkan potensi masyarakat Cilegon dan sekitarnya melalui pendidikan. Ia mendirikan sebuah pesantren dengan nama Pesantren Al-Khairiyah dengan mengambil tempat di daerah asalnya, yaitu Citangkil. Kiai Syam'un berkeinginan agar keberadaan Pesantren Al-Khairiyah menjadi suatu lembaga yang bermanfaat bagi perkembangan dan kesejahteraan umat manusia khususnya daerah Cilegon dan Banten. Keinginan dan harapan Kiai Syam'un menjadi kenyataan. Pesantren Al-Khairiyah mengalami perkembangan yang sangat pesat. Sejak tahun 1916 sampai tahun 1930 Pesantren Al-Khairiyah Citangkil berhasil memasuki masa keemasan. Pesantren AlKhairiyah dapat mengimbangi sekolah Pemerintah Belanda di Wilayah Cilegon. Pada masa perang kemerdekaan, ulama Banten di samping sebagai tokoh agama, juga mampu memegang jabatan di pemerintahan. Jabatan yang dipegang adalah jabatan residen, bupati, wedana, sampai birokrasi di bawahnya. Ulama Banten yang memegang jabatan di pemerintahan, antara lain; KH. Ali Jaya di Delingseng (Pulomerak-Cilegon); dan KH. Abdul Haq di Padarincang (Ciomas-Serang).
\end{abstract}

Kata kunci: Al-khairiyah, pesantren, Cilegon.

\section{Abstract}

Education is considered to be affecting in fighting colonialism in Cilegon, Banten. K.H. Syam'un built a pesantren called Pesantren Al-Khairiyah in Citangkil to fulfill the need, with the hope that it could be beneficial to the development and prosperity of humankind especially in Cilegon and Banten. The pesantren reached its golden age between 1916-1930. It could compete with school administered by the Dutch.

Keywords: Al-Khairiyah, pesantren, Cilegon. 


\section{A. PENDAHULUAN}

Pesantren adalah lembaga pendidikan Islam yang tidak hanya berfungsi sebagai lembaga pendidikan semata, tetapi juga berfungsi sebagai salah satu benteng pertahanan umat Islam, pusat dakwah, dan pusat pengembangan agama Islam di Indonesia. Pada masa sebelum kemerdekaan, pesantren telah memainkan peranan besar dalam meningkatkan pengetahuan agama dan menjadi pilihan utama bagi pendidikan masyarakat Indonesia.

Seiring dengan perkembangan zaman dan mulai maraknya sistem pendidikan formal, pesantren pun terus berperan untuk mengikutinya. Perkembangan ini sudah sejak awal abad ke-20, dengan berdirinya pesantren modern dan atau berubahnya pesantren tradisional menjadi pesantren modern. Pada pesantren ini telah terjadi pergeseran orientasi, tidak hanya mengajarkan masalah uhkrowi (keagamaan) semata tetapi juga masalah keduniawian. Hai ini tercermin dari penyesuaian kehidupan pesantren dalam menghadapi zaman yang semakin maju.

Salah satu pesantren tradisional yang telah berkembang menjadi pesantren modern adalah Pesantren Al-Khairiyah Kota Cilegon. Pesantren yang berdiri sejak 1924, memiliki peranan penting dalam perjuangan kemerdekaan Indonesia. Pemimpin Pesantren Al-Khairiyah Kota Cilegon ikut berperan aktif dalam perjuangan kemerdekaan Indonesia sejak masa penjajahan Belanda. Berdasarkan uraian di atas, maka dirasakan perlu dilakukan penelitian mengenai pesantren, terutama perjalanan sejarah Pesantren Al-Khairiyah Kota Cilegon. Penelitian mengenai perkembangan pendidikan pesantren di Indonesia sudah banyak. Namun, penelitian tentang sejarah Pesantren Al-Khairiyah belum dilakukan.

Sejarah Pesantren Al-Khairiyah Kota Cilegon secara tematis dan geografis merupakan sejarah lokal. Dengan demikian, penulisan Sejarah Pesantren Al-Khairiyah Kota Cilegon sedikitnya dapat menangkal hilangnya sebagian peristiwa sejarah dari panggung sejarah Indonesia. Selain itu, pengungkapan sejarah ini dapat menambah khasanah sejarah Indonesia, khususnya sejarah lokal daerah Banten.

Metode yang digunakan dalam penelitian adalah metode sejarah, terdiri atas tahapan heuristik, kritik, interpretasi dan historiografi. Pada tahap heuristik, pencarian dan pengumpulan sumber dilakukan dengan mencari dan menghimpun data tulisan berupa dokumen-dokumen mengenai sejarah Pesantren Al-Khairiyah. Pada tahap kritik, untuk mendapatkan data yang akurat dan objektif akan dilakukan pengujian terhadap data yang diperoleh. Selanjutnya, pada tahap interpretasi, data mengalami proses pemberian makna dan penafsiran sehingga fakta-fakta tersebut dapat menjelaskan objek studi secara jelas. Proses terakhir, adalah historiografi yang bertujuan untuk merangkaikan fakta-fakta yang berhasil dihimpun dalam sebuah jalinan kisah sejarah yang relatif objektif.

\section{B. HASIL DAN BAHASAN}

\section{Latar Belakang Berdirinya Perguruan Al Khairiyah}

Belum ditemukan sumber yang menyatakan secara jelas, sejak kapan berdirinya pondok pesantren di Indonesia. Data tertulis tentang lembaga-lembaga pendidikan tradisional di Indonesia yang ditemukan yaitu dari laporan pemerintah Belanda tahun 1831 yang menyebutkan bahwa pada tahun 1853 terdapat lembaga pendidikan Islam tradisional dengan jumlah murid 14.929 orang. Jumlah itu meningkat lagi dalam laporan tahun 1885 menjadi 16.556 di seluruh Jawa-Madura, kecuali Kesultanan Jogyakarta. Jumlah murid pada saat itu sekitar 222.663 (Yacub, 1984: 66$67)$.

Pada akhir abad ke-19 perkembangan pesantren berkembang sangat pesat dengan indikatornya ialah bertambah banyak umat Islam menunaikan ibadah haji ke Mekah. Ada beberapa ulama yang berasal dari Jawa seperti Syekh Nawawi dari Banten, Syekh Mahfudz dari Pesantren Tremas menjadi staf pengajar tetap di Masjidil Haram Mekah dan mereka itu 
diakui kebesarannya di Timur Tengah. Banyak pondok pesantren ketika itu yang telah mapan dan kuat (Yacub, 1984: 67).

Eksistensi pondok pesantren pada suatu kawasan tertentu berbeda sekali jika dibandingkan dengan adanya sekolah lanjutan pertama/lanjutan atas lainnya yang juga ada di daerah itu. Walaupun sekolah bentukan pemerintah Belanda itu dilengkapi dengan asrama pelajar dan perumahan guru, pengaruhnya terhadap warga masyarakat di sekitarnya tetap berbeda. Pada umumnya kontak lahir batin antara warga pondok pesantren dengan masyarakat di sekitarnya lebih bergema ketimbang hubungan antara sekolah nonpesantren dengan penduduk di sekelilingnya (Yacub, 1984:67). Malahan banyak pondok pesantren yang menjadi bagian tak terpisahkan dari masyarakat di kawasan tersebut.

Sejak awal keberadaannya sampai sekarang dan masa-masa yang akan datang, pondok pesantren, selain berfungsi sebagai lembaga pendidikan keagamaan, juga berperan sebagai pusat pengembangan masyarakat dan pusat pengembangan Sumber Daya Manusia (Departemen Agama, 2001: 2 ).

Perkembangan pesantren dari tahun ke tahun makin berkembang. Ketika pada tahun 1920-an pesantren besar hanya mengasuh 200 orang maka pada tahun 1930an jumlah santri pada pesantren besar melonjak dengan drastis mencapai lebih 1.500 orang (Hasmy,1993:53). Hal ini menunjukan perkembangan agama Islam di Indonesia sangat pesat.

\section{Pendiri Perguruan Islam Al Khairiyah}

Sejak semula para pendiri Republik menyadari bahwa Negara Republik Indonesia yang baru diproklamasikan kemerdekaannya itu hanya dapat berdiri utuh dan lestari dalam mencapai tujuan atau aspirasi nasional apabila didukung oleh manusia-manusia Indonesia yang dipersatukan oleh pandangan hidup yang sama yaitu Pancasila.

Untuk melahirkan manusia baru sebagai pelanjut, telah pula diletakkan dasardasar pendidikan yang bersifat nasional dan demokratif. Nasional dalam arti pendidikan yang sesuai dengan kebudayaan dan kebutuhan serta aspirasi bangsa Indonesia. Demokratif dalam arti bahwa pendidikan dan pengajaran adalah untuk rakyat secara merata, dan semua lapisan (anak-anak, pemuda, orang dewasa, laki-laki dan perempuan) tanpa membedakan golongan, suku, ras, tingkat sosial dan ekonomi. Dalam pembukaan UUD 1945 ditegaskan bahwa tujuan nasional antara lain adalah untuk mencerdaskan kehidupan bangsa. Artinya harus mendidik anak-anak dan rakyat Indonesia menjadi bangsa yang cerdas.

Untuk menyiapkan generasi pelanjut yang memiliki kesamaan pandangan hidup, memiliki wawasan perjuangan yang luas serta mampu mengatasi keutuhan material, terutama dalam mencapai kesejahteraan spritualnya, maka sekembalinya dari Tanah Suci, KH. Syam'un mulai merintis berdirinya suatu perguruan yang pada saat itu sudah dianggap maju dan dapat memenuhi panggilan kebutuhan bangsanya, yaitu Perguruan Islam Al-Khairiyah. Pada awalnya perguruan itu berbentuk pesantren, didirikan pada tahun 1916 oleh KH Syam'un bin Alwiyah di Citangkil, Desa Warnasari, Kecamatan Grogol, Kabupaten Serang Karesidenan Banten.

Berdirinya Pesantren Citangkil ini mempunyai kaitan erat dan nilai historis yang mengalami proses sejarah yang sangat panjang, yaitu merupakan kelanjutan perjuangan dan cita-cita merdeka sejak ratusan tahun sebelumnya dan telah banyak menelan korban manusia dan harta. Perjuangan kemerdekaan bangsa yang dikenal dengan Geger Cilegon (Perang Cilegon) dipimpin oleh KH Wasyid yang dipersiapkan sejak tahun 1884 kemudian meletus tahun $1888 \mathrm{M}$ (Djatnika, 1995:3-4). Sekalipun kelihatannya Geger Cilegon itu dapat ditumpas, namun kenyataannya semangat dan gerakan Geger Cilegon itu terus berjalan, baik itu yang dilakukan oleh para pejuang Geger Cilegon yang berada di tempat pengasingan maupun masyarakat sekitar Banten yang ikut menghayati gerakan itu, termasuk juga yang dilakukan oleh Siti Hajar putri KH Wasyid sendiri yang berusaha keras menyelamatkan adiknya Yasin Beji dan Syam'un, cucu Ki Wasyid ke Tanah Suci (Thaha, 2003:VIII-IX). 
Selama tinggal di Makkah, Syam'un menimba ilmu dengan belajar di Al-Azhar Kairo Mesir selama 4 Tahun dari tahun 1910-1814. Setelah selesai, Syam'un kembali ke Makkah dan menjadi guru di Masjidil Haram. Syam'un diakui sebagi orang alim yang disegani, banyak orang yang berguru kepadanya terutama orang-orang Banten dan Jawa yang datang untuk menuntut ilmu di Makkah.

Salah seorang kerabat K.H. Wasyid yaitu H. Abdul Azis Kartawirana berupaya melakukan pendekatan kepada Gubernur Jenderal Graaf van Lindurg dan Gobee (Advisor Voor Inlandschezaaken di Batavia) agar anak keturunan K.H. Wasyid dapat diperbolehkan kembali ke Banten.

Upaya yang dilakukan H. Abdul Azis Kartawirana untuk membawa pulang K.H. Syam'un membawa hasil, tetapi dengan jaminan nyawa beliau apabila kelak di kemudian hari anak cucu K.H. Wasyid melakukan pemberontakan.

Pada tahun 1915, keluarga K.H. Wasyib kembalui ke Banten, Ki Yasin menetap di Kampung Beji. Adapun Syam'un bersama ibunya $\mathrm{Hj}$. Sti Hajar menetap di Kampung Citangkil Desa. Warnasari. Di sinilah Syam'un menyusun kekuatan dengan mendirikan sebuah pondok pesantren untuk mendidik para pemuda sebagai kader pejuang dalam menuntut Indonesia merdeka (Thaha, 2003:VIII-IX).

\section{Pengertian Al-Khairiyah}

Al-Khairiyah berasal dari bahasa Arab, diambil dari kata khoirun artinya baik, kemudian menjadi Al-Khoiru yaitu lawan dari kata As-Syarru yang dimaksud adalah "berhasilnya sesuatu secara maksimal" atau dengan kata lain "yang banyak kebaikannya".

Dari pengertian Al-Khairiyah itu sendiri tersirat pengertian-pengertian lain seperti "kemuliaan dan kehormatan" kemudian berkembang menjadi "pilihan utama yang lebih baik" dan akhirnya menjadi kata Al-Khairiyah yang artinya; Kebajikan, kesucian, kemurahan dan kelebihan.

Salah satu sumber inspirasi atau yang mendorong KH. Syam'un untuk menetapkan nama Al-Khairiyah bagi Pesantrennya yaitu ketika beliau memperhatikan adanya suatu bendungan air di Mesir, yaitu bendungan Sungai Nil, yang dari bendungan itu dapat mengairi sekian luas lahan pertanian dan meningkatkan tingkat kesuburan di sekitar lembah sungai itu, sehingga dapat mengangkat taraf hidup rakyat di negeri tersebut. Bendungan itu bernama "Al-Khairiyah" (Muhyidin, 1990:59).

Sejak perkembangannya dari awal "Al-Khairiyah" berdiri di tempat-tempat lain selain di Citangkil, didasari karena khidmat kepada Guru dan ingin mengembangkan ilmu yang diperoleh dari gurunya sehingga ilmu yang diperolehnya menjadi ilmu yang bermanfaat, dan untuk hal ini diizinkan oleh KH Syam'un, Guru Besar dan sebagai Bapak Al-Khairiyah. Dari dasar itulah sehingga tercermin rasa keikhlasan dan tanpa pamrih dalam setiap usaha dan pengabdian yang dilakukan oleh segenap murid-muridnya dalam mengembangkan Perguruan Islam Al- Khairiyah. Jadi sematamata mengharapkan ridho ilahi $(\mathrm{H}$. Hikmatullah A. Syam'un, Wawancara 20 Mei 2010).

\section{Perkembangan Pesantren Al-Khairiyah}

Perkembangan Pesantren Al-

Khairiyah Citangkil sejak berdirinya pada tahun 1916 sampai dengan tahun 1925 sistem belajarnya belum secara klasikal, tapi masih ngaji sorogan atau ngalekor (duduk bersila dilantai) dan pusat kegiatan belajarnya adalah Masjid Agung Citangkil yang dibangun kembali oleh masyarakat setelah musnah akibat meletusnya Gunung Krakatau tahun 1883. Bahkan Mesjid ini ketika meletusnya Geger Cilegon menjadi salah satu Pusat Komando pertempuran antara pasukan KH Wasyid melawan Pasukan Penjajahan Belanda. Kini tempat bersejarah itu telah menjadi Kawasan Industri berat PT Krakatau Steel dan Mesjid itu berada di tengah-tengah kawasan tersebut.

Sistem belajarnya sederhana sekali dan tidak terkait dengan waktu, sekali waktu membuka kitab di Mesjid, kadang-kadang di perjalanan, kadang-kadang seketika itu juga 
harus mengangkat senjata melawan musuh. Akan tetapi hubungan antara Santri dan Kiai atau Guru/Ajengan merupakan ikatan keluarga bagaikan anak-anak dengan orang tuanya (Bapak). Hubungan ini tidak pudar dimakan usia atau ditelan kehidupan, dalam arti hubungan keluarga tersebut hubungan dunia akhirat (Muhyidin, 1990:56).

Namun demikian, para santri asuhan dan gemblengan KH Syam'un, berhasil menjadi kader-kader yang militan yang sanggup berjuang di medan tempur dan diplomasi seperti KH Abdul Fatah Hasan, sebagai anggota Panitia Perumus Inti Pancasila dan UUD 1945. Selain itu, ada pula para santri yang mempunyai jabatan dalam pemerintah Republik Indonesia yang baru diproklamasikan, baik di Banten maupun di daerah lain. Mereka itu antara lain:

1. KH.Ahmad Ambon - Amboina Maluku.

2. KH.Ali Jaya - Delingseng (Pulomerek-Cilegon).

3. KH.Mahmud - Nyamuk (Bojonegara-Cilegon).

4. KH.Ahmad Naja - Kamasan (Cinangka- Anyar).

5. KH.Resimen - Rancaranji (Padarincang-Ciomas).

6. KH.Abdul Haq - Padarincang (Ciomas-Serang).

7. KH.Mohammad Nor - Kramat Watu (Serang)

8. Ki.Syarbini - Pangloreng (Bojonegara-Serang).

9. KH.Syadeli - Kejayan (Kramat Watu-Serang).

10. KH.Ismail - Bunar (KeragilanSerang).

11. KH.Karna - Sumurwatu (Pulomerak-Cilegon).

12. Ki Rosyidin - Kubang Menyawak (Pulomerak Serang).

13. Ki.Arifuddin (Pulomerak-Serang).

Citangkil

14. KH.Asy'ari (Pandeglang).

15. KH.Rofe'i - Barugbug (CiomasSerang).

16. Ki Moh. Sufi - Barugbug (CiomasSerang).
17. KH. Halimi - Citangkil (PulomerakCilegon).

18. KH.Abdul Jalil - Curawetan (Pulomerak-Cilegon).

19. KH.Buang - Bunar (KragilanSerang).

20. KH.Sohari - Pipitan (WalantakaSerang).

21. KH.Ali Akbar - Warung Gunung (Rangkasbitung Lebak).

22. KH. Musta'al - Pontang (Serang).

23. Ki Bakar - Beji (BojonegaraCilegon).

24. H. Hasa Bolang - Bolang (TirtayasaSerang).

25. KH.Halimi - Kubangkura (Pulomerak-Cilegon)

(Syam'un, 1972: 44)

Setelah sembilan tahun KH. Syam'un membina kadernya yang pertama dan utama itu, pada tahun 1925, KH. Syam'un bersama-sama dengan murid dan masyarakat sekitarnya dapat mendirikan gedung sekolah/madrasah terdiri atas 5 (lima) lokal yang diberi nama "Madrasah Al-Khairiyah Citangkil". Mulai saat inilah sorogan (ngalekor) dilengkapi dengan sistem klasikal.

Pada tahun 1930 KH. Syam'un memperluas dan menyempurnakan Madrasah Al-Khairiyah, sehingga Madrasah dan Pesantren Citangkil merupakan sebuah komplek pendidikan yang terdiri beberapa lembaga pendidikan termasuk membuka HIS Partikelir untuk menandingi dan mengimbangi Sekolah HIS Belanda yang ada di Cilegon. Tiga tahun sebelum lahirnya Sumpah Pemuda di Perguruan Islam AlKhairiyah termasuk HIS-nya telah menggunakan bahasa pengantar dengan bahasa Indonesia. (Syam'un, 1972: 45).

Sejak Al-Khairiyah ditingkatkan dari Pesantren menjadi lembaga pendidikan yang terorganisir pada tahun 1925, AlKhairiyah mencapai kemajuan dan puncak keemasannya. Pada saat itu, murid-murid yang datang bukan hanya dari daerah Banten, tetapi juga dari luar Banten, antara lain dari Lampung dan Sumatera Selatan.

Mulai dari tahun 1929 bermunculan Madrasah-madrasah "Al-Khairiyah" seba- 
gai cabang dari Madrasah Al-Khairiyah Citangkil.

1. Madrasah Ibtidaiyah di Kampung Delingseng, Desa Kebonsari Kecamatan Pulomerak (Ciwandan) Kabupaten Serang.

2. Madrasah Ibtidaiyah di Desa Kamasan, Kecamatan Cinangka, Kabupaten Serang.

3. Madrasah Ibtidaiyah di Kampung Kalumpang, Desa Ranca-ranji, Kecamatan Pandarincang Kabupaten Serang.

4. Madrasah Ibtidaiyah di Kampung Pipitan, Desa Kiara Kecamatan Walantaka Kabupaten Serang (Muhyidin, 1990:60).

Untuk mengatasi kebutuhan dana atau pembiayaan madrasah yang mulai berkembang dengan pesat, maka didirikanlah sebuah Koperasi yang diberi nama "Koperasi Bumi Putera Citangkil" diketahui oleh KH. Abdul Aziz (Mantan Kepala Kantor Kecamatan Cilegon).

Untuk mengelola dan mengorganisir madrasah secara baik dan teratur, pada tanggal 21 Juni 1931 didirikan organisasi "Jam'iyah Nahdlotusy Syubbanil Muslimin" (Perkumpulan Kebangkitan Pemuda Islam) bertempat di Citangkil dengan susunan Pengurus sebagai berikut:

Beschermeheer: KH. Syam'un, Direktur Madrasah Al-Khairiyah Citangkil.

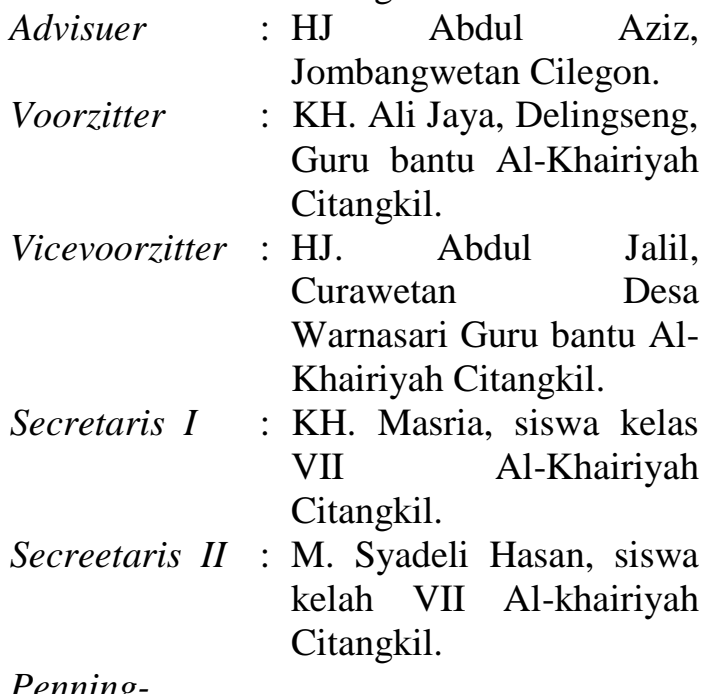

meester I : HJ. pengurus Citangkil.

Abdurrahman, Mesjid

Penningmeester II : Halimi Citangkil, Guru bantu Al-Khairiyah Citangkil.

Comisarisen:

1. M. Asy'ari, Padulisung Pandeglang, Guru Bantu Al-Khiriyah Citangkil.

2. H. Halimi Kabungkura Pulomerak siswa kelas VII Al-Khairiyah Citangkil.

3. H. Hasan Bolang, Kecamatan Pontang, siswa kelas VII AlKhairiyah Citangkil.

4. Qomaruzzaman, Pegantungan Serang, siswa kelas VII AlKhairiyah Citangkil.

5. Abdul Fatah Hasan, Beji Bojonegara Serang, siswa kelas VII AlKhairiyah Citangkil.

6. Shahim Bebulak Pulomerak, siswa Al-Khairiyah Citangkil.

7. Syibromelisi, Citangkil, siswa kelas VII Al-Khairiyah Citangkil.

8. Rasiman, Kalumpang Kecamatan Pandarincang, Guru bantu AlKhairiyah Citangkil.

9. M. Sufi, Barugbug Kecamatan Padarincang, Guru bantu AlKhairiyah Citangkil.

10. M. Rafe'i, Barugbug Kecamatan Padarincang, Guru bantu AlKhairiyah Citangkil.

11. Thahir, Temuputih Ciwedus Kecamatan Cilegon siswa kelas VII Al-Khairiyah Citangkil.

12. Rasyidi, Beji Bojonegara Kabupaten Serang, siswa kelas VII AlKhairiyah Citangkil

(Muhyidin, $1990: 62$ )

Perkembangan Organisasi

Siswa-siswa/lulusan Al-Khairiyah Citangkil, merupakan kader-kader dan pengembang Al-Khairiyah yang jumlahnya cukup banyak. Sebagian menjadi guru bantu di Al-khairiyah Pusat Citangkil, sedangkan yang lainnya mendirikan Masrasah- 
madrasah Al-khairiyah di daerahnya masing-masing sebagai Madrasah cabang. Pada tahun 1933 jumlah Madrasah cabang Al-Khairiyah telah mencapai 15 (lima belas) cabang, yang keberadaannya di bawah pengelolaan organisasi Nahdlotusy Syubbanil Muslimin. Untuk mempersiapkan kader yang berpendidikan akademis, pada tahun 1933 KH. Syam'un berangkat ke Mesir mengantarkan 2 (dua) orang pemuda lulusan Al-Khairiyah Citangkil untuk melanjutkan pendidikan di Al-Azhar University yaitu:

1. Abdul Fatah Hasan.

2. M. Syadeli Hasan.

Keduanya adalah kakak beradik dari Beji, Desa Bojonegara Kabupaten Serang.

$$
\text { Pada tahun } 1934 \text { struktur }
$$

Madrasah Al-Khairiyah Citangkil atau sistem pendidikan Madrasah pusat mengalami perubahan yang semula masa belajar yang harus ditempuh:

1. Kelas No 1 (Awaliyah) : 1 Tahun.

2. Kelas 2 (Tahdiriyah) $: 1$ Tahun.

3. Kelas I $: 1$ Tahun.

4. Kelas II $: 1$ Tahun.

5. Kelas III $: 1$ Tahun.

6. Kelas IV $: 1$ Tahun.

7. Kelas V : 1 Tahun.

8. Kelas VI : 1 Tahun.

9. Kelas VII $: 1$ Tahun.

Dari seluruhnya 9 (sembilan) tahun menjadi hanya tiga tingkatan :

1. Madrasah Ibtidaiyah (sekolah dasar) dengan masa belajar 6 (enam) tahun.

2. Madrasah Tsanawiyah (SLTP) dengan masa belajar 3 tahun.

3. Madrasah Mu'alimin (pendidikan Guru) 2 (dua) tahun, seluruhnya melalui masa 11 (sebelas) tahun (Dokumen PB Al-Khariyah, t.t).

Tahun 1936 di Pusat Perguruan

Islam Al-Khairiyah Citangkil didirikan sekolah umum dengan nama HIS (Hollandsch Inlandsch School) dengan masa belajar 3 (tiga) tahun, untuk mengimbangi sekolah-sekolah yang dibentuk oleh pemerintah Belanda dengan tenaga-tenaga Guru sebagai berikut :

1. Meneer Chussnun Achyar, Grogol Pulomerak
2. Meneer Idris, Siswa Al-Khairiyah Citangkil, berasal dari Bandung Jawa Barat.

3. Meneer Abdurrohman, Siswa AlKhairiyah Citangkil berasal dari Kupang Teba, Tanjungkarang Lampung.

4. Meneer Sahdi, Siswa Al-Khairiyah Citangkil, berasal dari Cianjur Jawa Barat.

5. Meneer Asyikin Hamim, Siswa AlKhairiyah Citangkil berasal dari Kupang Teba, Tanjungkarang Lampung.

6. Meneer Syahsiam, Siswa AlKhairiyah Citangkil, berasal dari Cianjur Jawa Barat (Muhyidin, 1990:63).

Tahun 1940 dua orang siswa AlKhairiyah yang melanjutkan pendidikannya di Mesir, kembali ke tanah air, karena telah menyelesaikan perkuliahannya dan telah lulus/berijazah.

1. KH. Abdul Fatah Hasan, lulus dari Al-Azhar University.

2. KH. M Syadeli Hasan, di samping lulus dari AL-Azhar University, juga lulus dari Daarul Ulum University. Kemudian beliau mengajar di AlKhairiyah Citangkil pada tingkat Tsanawiyah dan Mu'alimin.

Tahun 1951 Mahdatusy Syubanil Muslimin diubah namanya menjadi "Perguruan Islam AL-Khairiyah" yang berpusat di Citangkil. Hal ini di samping demi kemajuan dan kesempurnaan organisasi, juga karena faktor lain yang mendorong adanya penyempurnaan dan perubahan pengurus organisasi disebabkan banyak pengurus yang telah meninggal dunia dan sebagian besar disebabkan untuk mengisi jabatan pemerintahan, ketentaraan dan lain-lain karena memang dibutuhkan oleh negara dan bangsa.

$$
\text { Periode pertama Pengurus }
$$

Perguruan Islam Al-Khairiyah Citangkil adalah sebagai berikut :

$\begin{array}{lll}\text { 1. Ketua } & \text { Ustadz Masria, } \\ & \text { Guru Al- } \\ & \text { Khairiyah } \\ & \text { Citangkil. } \\ \text { Abdullah }\end{array}$

Ahmad, Guru 
Al-Khairiyah

Citangkil.

3. Sekretaris : S.Misbach, Guru

Al-Khairiyah

Citangkil.

4. Wakil Sekretaris : Muslih

Sakim,

Guru SD

Krenceng-

Pulomerak

5. Bendahara

: Moh. Isa, Guru

Al-Khairiyah

Citangkil.

6. Pembantu

: Ustadz Muslim,

Guru

Khairiyah

Citangkil.

7. Pembantu : Moh. Sidik, Guru

Al-Khairiyah

Citangkil.

8. Bag. Pendidikan : Ustadz

Syibromelisi,

Guru

Al-

Khairiyah

Citangkil.

9. Bag. Pendidikan : Ustadz Abubakar,

Guru

Al-

Khairiyah

Citangkil.

10. Sekr. Pendidikan : Sayuni, Siswa Al-

Khairiyah

Citangkil.

11. Pembantu

: Ustadz

Salim,

Guru

Al-

Khairiyah

Citangkil.

12. Bag. Bangunan : Sarmidi, Tokoh Masyarakat

Citangkil.

13. Sekret Bangunan : Moh. Syadeli,

Tokoh

Masyarakat

Citangkil.

14. Bedah. Bangunan: H Siradj, Siswa

Al-Khairiyah

Citangkil.

15. Pembantu

- Abdul

Siswa

Gani,

Khairiyah

Citangkil.

16. Penasehat

: KH. Ali Jaya, Wedana Anyer
17. Penasehat

18. Penasehat

Al-

mar/Kongres Perguruan Islam Al-Khairiyah yang pertama kali, dihadiri oleh Pengurus Pusat dan Pengurus Cabang yang pada saat itu telah mencapai 121 (seratus dua puluh satu) cabang/madrasah. Melalui Muktamar, telah diambil keputusan sebagai berikut:

1. Semua Madrasah yang merupakan cabang dari Perguruan Al-Khairiyah Citangkil harus menggunakan nama yang sama (seragam) yaitu Madrasah "Al-Khairiyah".

2. Mata pelajaran yang dipergunakan, diseragamkan menurut kurikulum/ syilabus yang ditetapkan oleh Perguruan Islam Al-Khairiyah Pusat.

3. Ditetapkanya adanya Anggaran Dasar dan Anggaran Rumah Tangga Al-Khairiyah.

4. Mengesahkan susunan Pengurus Perguruan Islam Al-Khairiyah Citangkil.

Pada muktamar atau kongres saat itu dibentuk pengurus Perguruan Islam AlKhairiyah. Adapun susunan kepengurusan tersebut, yaitu:

Ketua Umum : KH. N Syadeli Hasan

Ketua I

: Ustadz Masria

Ketua II : Ustadz Abdul Kohar Hasan

Sekretaris Umum : Ustadz Rahmatulloh Syam'un

Sekretaris I : Ustadz S. Misbach

Sekretaris II : M. Thohuri Salam

Pembantu : 1 . Usradz Syibromelisi Awi

2. Ustadz M. Isya

3. Ustadz Sahim 


\begin{tabular}{|c|c|}
\hline & 4. Ustadz Abu Bakar \\
\hline & 5. Ustadz Abdul \\
\hline & Kohar Rahim \\
\hline & 6. Nyi Hasunah \\
\hline Seksi Pendidikan & $:$ \\
\hline Ketua & : Ustadz Syibromeli Awi \\
\hline Sekretaris & : M. Thohuri Salam \\
\hline Pembantu & : 1. Nyi Hasunah \\
\hline & 2. Ustadz Rahmatulloh \\
\hline & Syam’un \\
\hline & 3. Ustadz Sahim \\
\hline Bendahara & $:$ \\
\hline Ketua & : Ustadz Abdullah \\
\hline Sekretaris & : Ustadz S. Misbach \\
\hline Pembantu & : Ustadz M Sidik \\
\hline Seksi Penerangan & : \\
\hline Ketua & : Ustasz Abu Bakar \\
\hline Sekretaris & : Ustadz S. Misbach \\
\hline Pembantu & : Ustadz M Sidik \\
\hline Dewan Pertimban & gan Dan Fatwa: \\
\hline Ketua & : KH. Ali Jaya \\
\hline Sekretaris & : Ustadz Abdullatif \\
\hline Anggota & : 1. KH. Suhari \\
\hline & 2. KH. Arifuddin \\
\hline & $\begin{array}{l}\text { 3. Ustadz M. Thohir } \\
\text { Hanafi }\end{array}$ \\
\hline
\end{tabular}

Panitia Kecil Pendidikan :

$\begin{array}{ll}\text { Ketua } & : \text { Ustadz Syibromelisi } \\ \text { Sekretaris } & : \text { Awi } \\ \text { Anggota } & : \text { 1. Ustih Sakim } \\ & \text { 2. Nyi Hasunah } \\ & \text { 3. M. Thohuri Salam } \\ & \text { 4. Ustadz M. Syadeli } \\ & \text { 5. Ketuan } \\ & \text { Komesariat Al- } \\ & \\ & \end{array}$

(Dokumen PB Al-Khairiyah)

Tahun 1956, kembali Perguruan Al-Khairiyah Citangkil dapat mengirimkan 4 (empat) orang siswa ke Mesir untuk melanjutkan belajar di Universitas Al-Azhar yaitu :

1. Rahmatulloh Syam'un (putra Pendiri AlKhairiyah)

2. Qurtubi Jannah

3. Abdul Wahab Arif
4. Sufri Muslim

Kemudian pada tahun 1960,

Perguruan Islam Al-Khairiyah Citangkil

dapat mengirimkan lagi 3 (tiga) orang siswa untuk melanjutkan belajar di Perguruan Tinggi Madinah di Saudi Arabia yaitu:

1. Fathullah Syam'un (putra Pendiri Al-Khairiyah)

2. Syamhudi Abduh

3. M. Saju Rajak

(Syam'un, 1972: 46)

Pada tahun 1930 Al-Khairiyah Citangkil telah berhasil memasuki masa keemasan AL-Khairiyah di bawah pimpinan KH. Syam'un "Bapak Al-Khairiyah dan betul-betul dapat mengimbangi sekolahsekolah Pemerintah imperialis Belanda khususnya di Wilayah Cilegon. Kendatipun demikian Al-Khairiyah Citangkil tetap dikenal dengan sebutan "Pesantren Citangkil". Madrasah-madrasah Al-Khairiyah mulai bermunculan di mana-mana dan berdiri sebagai cabang dari Al-Khairiyah Citangkil. Cabang-cabang itu antara lain:

\section{Sistem Pendidikan Perguruan Islam Al- Khairiyah}

Visi dan Misi Perguruan Islam Al-Khairiyah Membaca sejarah Banten secara kronologis, maka yang dapat kita perhatikan adalah kontinuitas "Perjuangan" oleh para pemimpin agama atau ulama, umaro dan pengikut atau masyarakatnya. Perlu disadari bahwa "Perjuangan" apa pun yang lakukan memerlukan banyak pengorbanan, tapi bukan berarti "menjadi korban". Suatu perjuangan tidaklah akan menemui arti bagi hidup dan kehidupan tanpa didasari oleh suatu "Idealisme" atau suatu harapan sebagai titik tolak bagi perjuangan manusia.

Setiap manusia yang berjuang sudah tentu memiliki "idealisme" (harapan mulia), tanpa idealisme tertentu perjuangan tidak akan mencapai titik kulminasi yang diharapkan. Oleh karena itu setiap perjuangan harus dilandasi idealisme, yaitu suatu cita-cita, harapan dan tujuan yang dapat mendorong bagi kelangsungan hidup dan kehidupan manusia untuk mencapai apa yang diharapkan. 
Seperti halnya "Perguruan Islam AlKhairiyah" yang didirikan oleh KH. Syam'un mempunyai "idealisme" yang mengarah pada tujuan dan prospek hidup umat manusia (masyarakat Banten khususnya). Idealisme perguruan Islam AlKhairiyah tidak jauh berbeda dengan apa yang diharapkan oleh pemerintah dewasa ini. Secara hakiki idealismenya adalah "meningkatkan kualitas manusia Indonesia". Yaitu manusia yang bebas untuk beribadah dalam rangka meningkatkan keimanan dan ketaqwaan terhadap Tuhan Yang Mahaesa. Bebas menuntut ilmu pengetahuan dalam rangka meningkatkan kecerdasan dan keterampilan serta menumbuhkan kesadaran dalam berbangsa dan bertanah air.

Dengan bekal nilai ibadah dan ilmu pengetahuan manusia akan tumbuh kesadaran bahwa "dengan pendidikan segala persoalan akan dapat teratasi". Ide itulah yang nampak dicetuskan oleh KH Syam'un dalam usaha menyadarkan masyarakat Banten untuk mengusir penjajah dan melenyapkannya dari bumi Indonesia.

Perguruan Islam Al-Khairiyah bertujuan untuk menghimpun persatuan dan kesatuan warga Al-Khairiyah khususnya dan umat Islam pada umumnya melalui pendidikan. Karena memang Al-Khairiyah mempunyai tugas dan usaha pokoknya di bidang "pendidikan". Didirikannya AlKhairiyah ini merupakan "suatu usaha yang sebesar-besarnya untuk mendidik anak-anak muslim kepada kesopanan dan kesentosaan dunia dan akhirat". Demikian diungkapkan oleh K.H. Syam'un. Perjuangan Islam AlKhairiyah ini merupakan tiang semangat perjuangan yang mempunyai poros hitoris dengan Geger Cilegon atau Perang K.H Wasyid. 7 Juli 1885-1888) dan perjuangan kemerdekaan bangsa Indonesia yang mampu membuka pintu gerbang proklamasi 17 Agustus 1945.

Kembali pada Idealisme perguruan Islam Al-Khairiyah, perkataan AlKhairiyah yang dimaksudkan adalah tugas suci yang dilakukan oleh seseorang, dua orang atau lebih untuk suatu kebajikan dan kesejahteraan. Sekalipun kesejahteraan itu adalah relatif, namun menurut pengertian dan keyakinan warga Al-Khairiyah, bahwa kesejahteraan itu mempunyai dua lokasi yaitu:

1. Kesejahteraan selama di dunia

2. Kesejahteraan selama di akhirat.

Sudah tentu untuk mencapai kesejahteraan yang dimaksud di atas harus mempunyai ilmu pengetahuan dan untuk memiliki ilmu pengetahuan diperlukan suatu pendidikan. Pendidikan yang dimaksud adalah meliputi dua bidang, yaitu :

1. Pendidikan Agama

2. Pendidikan pengetahuan umum Jika kedua pengetahuan itu sudah dimiliki, maka akan timbul suatu kesadaran dan keseimbangan pada diri manusia. Dapatlah kita katakan bahwa Perguruan Islam Al-Khairiyah sebagai salah satu lembaga pendidikan untuk mengolah dan membimbing warganya agar beridentitas satu dan mempunyai keseragaman untuk mencapai kesejahteraan dunia dan akhirat. Adapun keseragamannya diusahakan menuju kepada :

1. Keseragaman dalam tekad (i'tikad) beragama;

2. Keseragaman dalam bentuk organisasi

3. Keseragaman dalam disiplin organisasi;

4. Keseragaman dalam cara kerja berorganisasi;

5. Keseragaman dalam cara hidup berorganisasi;

6. Keseragaan dalam cara hidup bermasyarakat;

7. Keseragaman dalam hidup bernegara. Idealisme perguruan Islam AlKhairiyah mengimplikasikan satu kesatuan umat manusia yang sadar akan diri dan orang lain. Sadar akan eksistensinya untuk mencapai suatu tujuan, yaitu menuju kesejahteraan lahir dan batin, dunia dan akhirat.

Idealisme merupakan suatu keyakinan yang ada pada diri manusia sebagai penentu dan pedoman bagi perjuangan hidupnya. Mau tidak mau dengan idealisme itulah seseorang akan dapat menentukan cara hidupnya. Seperti juga idealisme dalam Perguruan Islam AlKhairiyah akan dapat menentukan arah bagi para pejuang, seperti dilakukan oleh $\mathrm{KH}$ Syam'un. Idealisme keyakinan ini 
merupakan bagian filsafat hidup yang berfungsi untuk menentukan arah ke mana dan untuk apa perguruan Islam Al-Khairiyah itu. Bertolak dari keyakinan tersebut, maka idealisme Perguruan Islam Al-Khairiyah diletakkan pada "manusia"nya. Adapun idealismenya adalah : untuk diarahkan ke mana dan dijadikan manusia macam apa umat Islam ini? Jenis masyarakat macam apa yang ideal, harus kita bina dan nilai apa yang harus kita tanamkan melalui Perguruan Islam Al-Khairiyah. Idealisme semcam ini yang senantiasa menggerakkan K.H Syam'un untuk berjuang dengan penuh semangat dan penuh tanggung jawab mencapai tujuan.

KH Syam'un dengan penuh keyakinan dan idenya mampu mengatasi segala persoalan yang sedang dihadapi masyarakat. Keresahan dan kesenjangan yang ada antara kaum intelektual dengan Ulama mengenai penekanan sekolah umum dan sekolah agama. Namun demikian kesenjangan itu dapat diatasi dengan cara yang efektif, yakni dengan Pendidikan Perguruan Islam Al-Khairiyah. Adapun langkah yang ditempuh adalah "mengintegrasikan" sekolah atau pendidikan umum dengan pendidikan agama. Jadi idealisme Perguruan Islam Al-Khairiyah adalah memadukan pendidikan (sekolah umum dengan sekolah agama) sesuai dengan tujuannya "kesejahteraan dunia dan akhirat".

Perlu disadari bahwa perjuangan yang dilakukan oleh K.H Syam'un khususnya dan pejuang lainnya. Pada intinya adalah menuntut hak asasi manusia untuk dijadikan sandaran horizontal dan vertikal yang menyangkut "kebebasan merdeka" untuk berbuat dan bertindak sesuai dengan kewajibannya. Nampaknya perjuangan K.H Syam'un tidak sekadar merupakan "idealisme" belaka, namun lebih dari itu perjuangannya telah menjadi kenyataan yang dapat dirasakan dewasa ini.

\section{PENUTUP}

Perjuangan masyarakat Cilegon khususnya dan Banten umumnya, menghadapi kaum penjajah dilakukan dengan berbagai cara. Cara yang dianggap paling efektif untuk menghadapinya adalah melalui pendidikan, mendirikan dan membangun sekolah, membimbing umat manusia lewat pendidikan. Dengan pendidikan inilah manusia bisa membuka mata, dapat membedakan yang hak daripada yang batil dan wawasan berpikir tentang kehidupan kian menjadi luas.

Dari pemikiran tersebut, K.H Syam'un sebagai salah seorang Ulama di Cilegon, mempunyai harapan dan idealisme yang tinggi untuk mengembangkan potensi masyarakat Cilegon dan sekitarnya melalui pendidikan. Hasil karya yang terwujud dari harapan dan idenya melalui proses perjuangannya adalah didirikannya sebuah pesantren dengan nama Pesantren AlKhairiyah dengan mengambil tempat di daerah asalnya yaitu Citangkil.

Dasar pemikiran K.H. Syam'un mendirikan sebuah pesantren adalah bahwa pesantren dianggap baik dan berguna dan mempertahankan fungsi pokok tujuan hidup manusia, yaitu sebagai tempat menyelenggarakan pendidikan agama. Akan tetapi diperlukan suatu tinjauan sedemikian rupa sehingga ajaran-ajaran agama yang diberikan kepada setiap pribadi merupakan jawaban yang selengkap-lengkapnya (komprehensif) mungkin atas persoalan makna hidup dan makna ajaran Islam, selain tentu saja disertai dengan pengetahuan secukupnya tentang kewajiban-kewajiban praktis sehari-hari seorang muslim.

Kiai Syam'un berkeinginan dengan keberadaan Pesantren Al-Khairiyah menjadi suatu Lembaga yang berfaedah dan bermanfaat bagi perkembangan dan kesejahteraan umat manusia khususnya daerah Cilegon dan Banten. Hendaknya lembaga ini menjadi suatu wadah yang mampu mengembangkan potensi-potensi anak didik, sehingga menjadi manusia yang berguna bagi dirinya dan bangsa serta agamanya.

Keinginan dan harapan Kiai Syam'un menjadi kenyataan. Perjalanan Pesantren mengalami perkembangan yang sangat pesat. Pada saat berdiri pada tahun 1916, Pesantren Al-Khairiyah hanya menerima murid yang berasal dari daerah sekitarnya dengan sistem pendidikan seperti pada pesantren umumnya yaitu sorogan dan ngalekor. Namun dalam perkembangan 
selanjutnya, Pesantren Al-Khairiyah mengalami kemajuan dengan banyaknya orang tua yang memasukkan siswanya belajar di pesantren ini. Mereka tidak saja datang dari daerah Cilegon dan Banten saja, juga dari Lampung dan Sumatra Selatan. Menghadapi kenyataan ini, Kiai Syam'un dengan persetujuan muridnya yang dianggap dapat membantunya mengembangkan Pesantren Al-Khairiyah menjadi sebuah madrasah dengan membangun lima ruangan sebagai tempat belajar para siswa.

Sampai tahun 1930 Al-Khairiyah Citangkil telah berhasil memasuki masa keemasan Al-Khairiyah di bawah pimpinan KH. Syam'un "Bapak Al-Khairiyah dan betul-betul dapat mengimbangi sekolahsekolah Pemerintah Belanda khususnya di Wilayah Cilegon. Kendatipun demikian AlKhairiyah Citangkil tetap dikenal dengan sebutan "Pesantren Citangkil". Madrasahmadrasah Al-Khairiyah mulai bermunculan di mana-mana dan berdiri sebagai cabang dari Al-Khairiyah Citangkil. Sampai tahun 1950, jumlah cabang dari Al-khairiyah yang tersebar di seluruh daerah Banten mencapai lebih dari seratus cabang.

Santri asuhan dan gemblengan $\mathrm{KH}$ Syam'un, berhasil menjadi kader-kader yang militan yang sanggup berjuang di medan tempur dan diplomasi seperti $\mathrm{KH}$ Abdul Fatah Hasan, sebagai anggota Panitia Perumus Inti Pancasila dan UUD 1945. Selain itu, ada pula para santri yang mempunyai kedudukan dalam pemerintah Republik Indonesia yang baru diproklamasikan, baik di Banten maupun di daerah lain. Mereka itu antara lain: KH. Ahmad Ambon di Ambon Maluku; KH. Ali Jaya di Delingseng (Pulomerak- Cilegon); KH. Abdul Haq di Padarincang (CiomasSerang).

\section{DAFTAR SUMBER}

1. Buku

Djamari. 1995.

$$
\begin{aligned}
& \text { "Ulama Kunci Pergerakan } \\
& \text { Perjuangan dan Pembangunan } \\
& \text { Bangsa", Dalam kumpulan }
\end{aligned}
$$

Karangan Banten Menuju Masa depan. Serang: Pemkot Propinsi Banten.

Djatnika. Rahmat. 1995

"Perjuangan K.H. Wasyid dan

Para Ulama Banten Lainnya Menentang Kolonialisme Belanda

", Dalam kumpulan Karangan

Banten Menuju Masa Depan.

Serang: Pemkot Propinsi Banten.

Indonesia. Depag. 2001.

Visi dan Misi, Serta Program

Pendidikan Keagamaan dan

Pondok Pesantren. Jakarta:

Direktorat Jenderal Kelembagaan

Agama Islam.

Hasymy, A. 1993.

Sejarah Masuk dan

Berkembangnya Islam di

Indonesia. Bandung: Almaarif.

Kartodirdjo, Sartono. et al. 1990

Sejarah Nasional Indonesia.

Jakarta: Depdikbud.

Muhyidin, Mansyur. 1990.

Karya Seorang Prajurit Banten:

Kyai Haji Syam 'un. Cilegon-

Banten: Perguruan Islam Al-

Khairiyah Citangkil.

Thaha, Idris. 2003.

"Kiai Jenderal Haji Syamun

Pejuang Kemerdekaan Asal

Banten". Amanah No 160. hal I-

VI

Syam'un, Rakhmatullah. 1972.

Riwayat Perjuangan Ki Syam'un.

Cilegon: tp .

Yacub. 1984

Pondok Pesantren dan

Pembangunan Masyarakat Desa.

Bandung: Angkasa.

2. Dokumen

Dokumen Pengurus Besar Al-Khariyah, t.t 
3. Informan

$\begin{array}{ll}\text { Nama } & : \text { KH. Fathullah Syam'un } \\ \text { Umur } & : \text { 72 Tahun } \\ \text { Alamat } & : \text { Jln. Agus Salim Cilegon } \\ & \\ \text { Nama } & : \text { H. Hikmatullah A. } \\ & \text { Syam'un } \\ \text { Umur } & : \text { 58 Tahun } \\ \text { Alamat } & : \text { Jl. Enggus Arja Citangkil } \\ & \text { Cilegon }\end{array}$

